been communicated to the Roval Society, and Dr. Harker is now engaged in carrying the investigation further-up to temperatures between $\mathrm{I0o0}^{\circ} \mathrm{C}$. and $2000^{\circ} \mathrm{C}$. 'This research includes an examination of the thermoelectric force of various platinum and platinum-alloy junctions, and of the effects of small percentages of impurity. The results of this work should be of high value to a great number of industries.

We have referred more especially above to the work which is being done in the physics department, but we might equally have quoted from the work of the other departments. For example, in the engineering department important work is in hand in connection with wind pressure, with the specific heat of superheated steam, and with the determination of the physical properties of "a series of nickel-steel alloys prepared for the laboratory by Mr. Hadfield. Similar examples might be taken from all the other departments, but space does not permit us to enter into further detail, and we must refer those particularly interested to the report, which is itself very condensed. Sufficient has been said, we trust, to give some idea of the importance of the work which the laboratory is carrying out and of the progress which has been made. It seems that the value of the institution is likely to be fully recognised by the technical public if one may judge by the steady increase in the number of tests which have been carried out. In r902, during nime months' working, 269 tests were made; last year this number increased to 1330 , which is equivalent to an increase of nearly 300 per cent.

Maurice Solomon.

\section{FERDINAND FOUQUÉ.}

$\mathrm{BY}$ the death of this illustrious geologist and mineralogist the ranks of science have lost one of their most notable chiefs. Half a century has passed away since he began that remarkable series of investigations which have contributed in so large a measure to the progress of vulcanology and petrography. In I $_{54}$, associated with St. Claire Deville, he published his earliest experiments on the losses effected by heat on minerals, but he was soon led into the domain of volcanic geology by studying the combustible gases given off from the flanks of Vesuvius. The eruption of Etna on January $3 \mathrm{I}, \mathrm{r} 8_{5}$, furnished him with opportunities of investigating the phenomena of a volcano in full activity, and the series of communications to the Paris Academy of Sciences recording his observations and deductions established his reputation as an accurate and accomplished chemist and mineralogist. The following year came the famous outburst of Santorin, and Fouqué, who had now taken enthusiastically to the subject, hastened to profit by the rare opportunities which this eruption afforded for the detailed study of volcanic phenomena. For several years he continued to publish the results of his visit and of his analyses of the rocks and gases which he had collected, finally embodying the whole elaborate investigation in his great monograph "Santorin et ses Eruptions," which appeared in 1879, and was at once hailed as one of the most important treatises that had yet been written in the domain of vulcanology.

While these studies were in progress he applied the modern microscopic methods to the investigation of volcanic rocks. After some years of successful labour in this field he associated himself with $\cdot M$. Michel-Lévy,' whose powers 'in' the determination of the optical characters of minerals and the minute structure of rocks pointed him out as an admirable No. I 795, voL. 6g] colleague in such a domain of research. Fouqué had given himself with the utmost ardour to the investigation of the optical characters of the felspars, a research in which he employed all the resources of modern chemistry and microscopy, which engaged his time and thought for some twelve years, and on which he justly prided himself as his most original contribution to science.

In the course of these inquiries his attention and that of his fellow-worker were directed to the importance of endeavouring to imitate the processes of nature by reproducing minerals and rocks artificially. In 1878 he published his "Synthesis of the Felspars," and in subsequent years the experiments were continued by the two observers through a series of trials in which they successively produced, by fusion and cooling, artificial compounds which, alike in chemical composition and minute structure, precisely resembled basic igneous rocks. From pyroxenic labradorite they were led to obtain in succession artificial leuco-tephrites, like the lavas of Vesuvius, basalts, diabases, dolerites and ophitic meteorites. The results of these researches were collected in the memorable "Synthèse des Minéraux et des Roches," the appearance of which in I882 marked an epoch in experimental geology. Up to the end, however, it was found impossible to reproduce artificially the acid rocks of granitic type.

MM. Fouqué and Michel-Lévy, while engaged in these inquiries, found also time for a detailed study of the minute structure and composition of the crystalline rocks of France, and embodied the results of this laborious investigation in the great quarto monograph "Minéralogie Micrographique: Roches éruptives Françaises," which, with one volume of text and another of admirable coloured plates, was published by the Geological Survey of France in 1879 .

The eminent petrographer was not merely one who relied on all the resources of a well equipped modern laboratory: He studied his subject in the field also. One great element of value in his volcanic investigations arose from personal acquaintance with the phenomena of active volcanoes. His knowledge of the eruptive rocks of his native country was likewise widened by prolonged examination of them on the ground. To him we owe some of the most interesting sheets of the map of the volcanic region of central France, where he traced the relations and order of sequence of the volcanic eruptions which give that part of the Continent such absorbing and perennial interest.

In his early years he had given some attention to the phenomena of earthquakes. Hence when the French mission was dispatched to study and report on the phenomena of the Andalusian earthquake of December 25. I 884 , Fouqué was placed at its head as director, associated with some of the ablest geologists in France. The massive quarto memoir containing the report of this mission is specially notable for the record of the experiments made by MM. Fouqué and Michel-Lévy to determine the rapidity of the propagation of waves of shock in different kinds of rocks. Fouqué likewise showed his continued interest in this subject by contributing in I 888 a little popular treatise, "Les Tremblements de Terre," to the Bibliothèque Scientifique Contemporaine.

For many years past the professor had given courses of lectures at the Collège de France, where also he carried on his chemical and petrographic researches. He lectured with his usual clearness and earnestness on Saturday, March 5. On the following evening he seemed in his usual health, and discussed petrographical subjects with his son-in-law, Prof. Lacroix, but next morning (March 7) he passed away in his sleep at the age of seventy-five. 
Gentle, modest and retiring, absorbed in his work, careless about worldly applause, and always happiest in the midst of his charming family, Fouqué was an example of one of the best types of a scientific man. His death makes an-irreparable blank in the scientific society of Paris, and has filled with sorrow the heart of everyone who had the privilege of his friendship.

A. G.

\section{NOTES.}

A IIEMORANDum by the financial secretary to the Treasury explaining the estimates for Civil Services and the Revenue Departments, 1904-5, was issued on Tuesday. The estimate for education, science and art, is $15,798,217 l$., which is an increase of $1,217,893 l$. above the amount for $1903-4$. The 1903-4 figures include a supplementary estimate of 45,00ol. for the relief of the National Antarctic Expedition - a service of a quite exceptional character, for which any provision that may prove to be necessary next year will be made in a similar form. The bulk of the addition arises on the vote for the Board of Education, as the result of recent legislation, but Public Education (Scotland), Public Education (Ireland), and Universities and Colleges (Great Britain) also show increases. The Board of Education (England and Wales) requires 985,131 . more than this year. Of this increase $50,5^{80 l}$. is for grants for training teachers, pupil teachers, \&c., and $52,303 l$. for grants in respect of education other than elementary. The principal increase, however $(889,888 l$.$) , is for grants towards expenditure on$ public elementary schools. Universities and colleges, Great Britain, will require an additional $32,100 l$. to provide for grants for the new universities at Liverpool and Leeds' (for each of which 20ool. is included), and for the proposed augmentation of the grants in aid of colleges, for which $54,000 l$. is inserted, or double the amount voted in the zurrent year.

A Reurer telegram from Vienna, dated March 19, states that at the request of the Academy of Science, the Austrian Minister of Agriculture, in order to facilitate the solution of certain important questions relating to the nature of radium, has ordered that from January I last until further notice no trading should be permitted in the residues from the manufacture of uranium colours at Joachimsthal, and that 10,000 kilogrammes of those residues should be reserved for purchase by the academy and another Io,ooo kilogrammes for $M$. and Madame Curie, in Paris. These consignments are to be devoted entirely to the purpose of scientific experiment.

AT Paris on Friday last M. and Madame Curie were honoured by the Municipal Council at the Hôtel de.Ville, and congratulated on their researches on radium. The two investigators were presented with silver medals bearing the inscription, "City of Paris to M. Pierre Curie and Mme. Marie Curie, Laureates of Nobel prize in 1902."

THE Washington Evening Star states that the U.S. Congress has granted $5000 l$. for the continuation of Dr. S P. Langley's experiments on aërial flight.

PRoF. ABBE, professor of physics at Jena, and Prof. Neumann, professor of mathematics at Leipzig, have been appointed members of the Bavarian Maximilian Order for Science.

THE British Medical Journal announces that two distinguished physiologists, Prof. Luigi Luciani, Rome, and Prot. Angelo Mnsso, Turin, have been named Senators of the Kingdom of Italy.

NO. I 795, VOL. 69]
THE death is announced, at the age of sixty-tive, of. M. Jules Garnier, known fur his explorations in New Caledonia and for his geological map of this district. His discovery of nickel ores in this French colony popularised the use of nickel in France, and was thus of material advantage to the colony. He was one of the founders of the French society of commercial geography.

A Number of letters have been appearing in the Times with reference to the electric railways to be constructed in the heart of the Snowdon district, which, it is urged by several correspondents, will greatly impair the natural beauties of the neighbourhood. The scheme includes the electrification of the narrow gauge "toy" railway from Dinas to Snowdon, the extension of this line through Beddgelert to Portmadoc, and also the construction of a branch line from Beddgelert through Pen-y-gwryd and Capel Curig to Bettws-y-Coed. These extensions have been sanctioned by the Light Railway Commissioners, and a Bill for a further extension from Dinas to Carnarvon was before a House of Lords Committee last week, the preamble of which it found proved. The railway will thus not only serve a district largely frequented by tourists, but will enable the slate from the quarries to be brought down easily to Carnarvon without the two or three changes of conveyance now necessary. It is also proposed to supply power to the quarries; the power is to be obtained from Llyn Llydaw, on the slopes of Snowdon, whence a pipe line will be run to the nearest point on the railway at which a generating station will be built.

THE completion of the electrical equipment of the Liverpool and Southport line of the Lancashire and Yorkshire Railway must be regarded as an important step in the progress of steam railway electrification. This is the second steam railway to be electrified, but the change is of more importance in this case than in that of the Mersey Railway on account of the fact that it is likely to lead to the electrification of all the suburlitan lines of the Lancashire and Yorkshire Railway, and possibly also of the London and North-Western Railway. The section which has just been electrified is nearly twenty miles in length; and has to deal almost entirely with passenger traffic. The effect of the electrification will be nearly to double the number of trains running between the two termini, and to reduce the time taken over the journey from 54 to 37 minutes. Power is generated at Fromby, nearly at the middle of the line, at 7500 volts three-phase; this is transformed down and converted to continuous current at 600 volts, at which pressure the train-motors are supplied. The current is collected from a third rail outside the track rails, and each train has two motor-cars, one at each end, with two trailers in between. It is pleasant to note, considering that all our electrical tramway equipment has been borrowed from America, that the whole of the equipment of this line is of English design and manufacture, the rolling stock having been made by the railway company, and all the rest of the work executed by Messrs. Dick, Kerr and Co.

THE figures published by Mr. J. W. Bradley, engineer to the City of Westminster, giving the results of tests on the different lamps employed in street lighting, are exceedingly valuable as the tests are made under actual working conditions and include all costs of maintenance, interest on capital, sinking fund, \&c. The results of the sixth series are published in the Electrician of March ri. From this series of tests Sugg's high pressure lamps in Parliament Street come out cheapest ( 7.65 pence per candle-power year), the arcs on the Westminster Supply Corporation 